Copyright (C) 2015 SBPjor / Associação Brasileira de Pesquisadores em Jornalismo

\begin{tabular}{l|l} 
Dossier & CAN STILL IMAGES TELI \\
& $\begin{array}{l}\text { STORIES? } \\
\text { photojournalism narrative theory } \\
\text { photom and temporality in }\end{array}$ \\
$\begin{array}{l}\text { ELIZA BACHEGA CASADEl } \\
\text { Universidade Estadual Paulista Julio de Mesquita Filho, São Paulo, } \\
\text { Brasil }\end{array}$
\end{tabular}

\begin{abstract}
Temporality is one of the central concepts in defining narrative. In this sense, photojournalism has always been a problem for narratological studies, since traditional image theories understand photography as a figure that immobilizes time. The aim of this paper is to discuss if photojournalistic practice is able to engender narratives or whether it is merely linked to description. Since traditional theories, linked to the realm of visible, expel temporality of photojournalistic narratives, we must give it back time to the image from another record: the visual. Our argument is that it is in the interchange of visible with the visual that narrative and temporality is given in photojournalism, in an image conception that does not take into account only the semiotic elements of photojournalism, but also its symptomatic aspects.
\end{abstract}

Keywords: Narrative. Temporality. Symptom. Visible Visual.

\title{
PODEM AS IMAGENS ESTÁTICAS CONTAR HISTÓRIAS? sintoma e temporalidade nas teorias da narrativa no fotojornalismo
}

RESUMO - A temporalidade é um dos conceitos centrais na definição da narrativa. Nesse sentido, o fotojornalismo sempre representou um problema para os estudos narratológicos, uma vez que as teorias tradicionais da imagem entendem a fotografia como uma figura que imobiliza o tempo, desprovida de duração. O objetivo do presente artigo é discutir se a prática fotojornalística é capaz de engendrar narrativas ou se se trata de uma atividade meramente ligada à descrição. Posto que as teorias tradicionais, ligadas ao domínio do visível, expulsam a temporalidade da narrativa fotojornalística, é necessário devolver o tempo à imagem a partir de um outro registro: o visual. Nosso argumento é o de que é justamente no entrecruzamento do visível com o visual que a narrativa e a temporalidade do fotojornalismo se urdem, em uma concepção de imagem que não leva em consideração apenas os elementos semióticos do fotojornalismo, mas também os seus aspectos sintomáticos.

Palavras-chave: Narrativa. Temporalidade. Sintoma. Visível. Visual 


\title{
¿PUEDEN LAS IMÁGENES FIJAS CONTAR HISTORIAS? \\ Síntoma y temporalidad en las teorías narrativas del fotoperiodismo
}

\begin{abstract}
RESUMEN - La temporalidad es uno de los conceptos centrales en la definición de narrativa. En este sentido, el fotoperiodismo siempre ha sido un problema para los estudios narratológicos, ya que las teorías tradicionales de la imagen entienden la fotografía como una figura que inmoviliza el tiempo, carente de duración. El propósito de este artículo es discutir si la práctica fotoperiodista es capaz de generar narrativas o si ella está simplemente ligada a la descripción. Dado que las teorías tradicionales, vinculadas al ámbito de lo visible, expulsan la temporalidad de la narrativa de fotoperiodismo, es necesario devolver el tiempo a la imagen en otro récord: el visual. Nuestro argumento es que en el cruzamiento del visible con la visual que está urdida la temporalidad en fotoperiodismo, en una concepción de imagen que no considera sólo los elementos semióticos del fotoperiodismo, sino también sus aspectos sintomáticos.

Palabras clave: Narrativa. Temporalidad. Síntoma. Visible. Visual.
\end{abstract}

Photojournalism has always been a problem for narrative studies. And that is because if it is possible to say that a picture tells a story in common sense, there is, in the different formal definitions of the term "narrative", a common element that represents an impasse for images that do not have time and motion as their imperative: that element is temporality.

In his classic essay on narrative, Genette (1980, p. 26) will define the term as follow: "a first meaning (...) has narrative refer to the narrative statement, the oral or written discourse that undertakes to tell of an event or a series of events". In "a second meaning, (...) narrative refer to the succession of events, real or fictitious, that are the subjects of this discourse, and to their several relations of linking, opposition, repetition etc.". At last, in "a third meaning (...) the act of narrating taken in itself". In these three perspectives, there is a temporal aspect that permeates the definition of narrative, whether from the point of view of a serial list of events, either from the chaining that these events assume in the text or from the act of developing the discourse that sustains a story. That is why, for Genette, "the temporality of written narrative is to some extent conditional or instrumental; produced in time, like everything else, written narrative exists in space and as space, and the time needed for consuming it is the time needed for crossing or traversing it, like a road or a field". Time, therefore, is primarily related to "connections between the temporal order of succession of the events in the story" (duration) "and the pseudo-temporal order of their arrangement in the narrative" (frequency) (GENETTE, 1980, p. 35).

Also in Metz (1991, p. 18), narrative is "a doubly temporal 
sequence, one must hasten to specify: there is the time of the thing told and the time of the telling (the time of the significate and the time of the signifier)". And that is why "one of the functions of narrative is to invent one time scheme in terms of another time scheme".

That is the central aspect that Paul Ricoeur (1990) emphasizes when he proposes that "there can be no thought about time without narrated time". Even the notion of intrigue, central to the narrative definition, only can be developed "thanks to the sequential interconnections the plot confers on the agents, their deeds, and their sufferings" (RICOUER, 1990, p. 57). And that is why the specificity of the narration act rests on the primary correlation between narrative and temporality (RICOEUR, 2012).

Comparing narrative to architecture, Ricoeur (2002, p. 11) draws a parallel between narrating and building, once both practices presuppose a configurator action. Architecture would be to space what report is to time: insofar the first action requires a built in space, narration suggests a plot built in the flux of time.

In this sense, photojournalism presents a problem for narrative studies, once it fixes temporality on an inert image. The image produced by photojournalism is a figure without duration because photography freezes the temporality of events. As Dubois (1993, p.161) has written, "temporally, in fact - it has already been repeated enough - photographic image stops, holds, fixes, immobilizes, highlights and separates duration, capturing a single moment of it". And so "the flow, the race, the Time has no validity in photography's point of view. The photographic act cuts; the shutter guillotines duration; it installs a kind of out-of-time (out of the race, hors-concours [out of competition])" (DUBOIS, 1993, p. 163).

If temporality is one of the main elements that forms the concept of narrative, such definitions have serious implications for photojournalism. Since it is stated that photojournalism freezes time (and, in addition, if we assume as valid the idea that photography is a device capable of telling a story), it is necessary to discuss how photojournalistic storytelling dialogues with the flow of time, despite its status as a static image. It is only from the understanding of photography's own temporality that we can examine how photojournalism constructs narrative.

From these considerations, the aim of this paper is to discuss photojournalism temporality despite its status of still image. From that, we will articulate an answer to the following question: would 
be photojournalism a device capable to produce stories? Historically, narratological approaches to static image is divided between the paradigm of the visible and the studies that take the concept of symptom as the main analysis element. Each one of these approaches has engendered a certain sense of "temporality" and a certain definition of "narrative". Based on these issues, we will propose an approach to photojournalistic narrative that articulates the structure (understood as the legibility in the field of visible) with the happening (based on the idea of symptom).

We assume here that photojournalism has a temporality and a duration, but these terms are not covered by the most current still image theories.

Didi-Huberman (2005, p. 30) says that the conceptual failure in thinking still images as apparatus without temporality is in trying to "comprehend the vast constellation of objects created by man in view of a visual efficacy when it tries to integrate them into the conventional schema of mastery of the visible". From this order of questions, it is necessary to integrate the visual domain to the temporality domain in photojournalistic image, so we can understand it as a narrative, as discussed below.

\section{NARRATIVE IN THE DOMAIN OF THE VISIBLE: TECHNOLOGY, COMPOSITION AND AUDIENCE}

To Cartier-Bresson (1952, p. 17), "photography is the simultaneous recognition, in a fraction of a second, of the significance of an event as well as of a precise organization of forms which give that event its proper expression". This statement summarizes some of the problems that photojournalism faces to be considered as a narrative form of expression. This is because the fraction of second that freezes the event and organizes it in a static form seems to contradict the photojournalistic pretension of telling something about the world because it is a practice that deviates from the ideas of duration and temporality (central elements to the narrative definition). In this point, then, lies the question: would be photojournalistic activity an action merely linked to the description and not to the narration of events? Although under the apparent lack of temporality and duration would photojournalism be able not only to show something, but to tell a story, to narrate a fact? 
As previously placed, we assume that yes: that photojournalism is able to articulate a narrative since it engenders a temporality and a duration of its own, despite its status as an inert image. This purpose, however, depends on a very specific understanding of both the question of the image and the temporality. It is inserted, therefore, in the symbolic and institutional arguments that try to define the status of these two terms.

Most methodologies that aim the study of static images eventually ignore these aspects, so that it is necessary to reinsert duration in photojournalistic image studies.

As Didi-Huberman (2013, p. 221 ) states, the problem of most methodological approaches that study static images is in the fact that they define it as a mechanism thought to work without remains. This means understanding image as something perfectly legible and fully decipherable, as if the eye were a pure organ, without passion. The author refers especially to those approaches that follow the iconological ideas of Erwin Panofsky for works of art's study; this paradigm, however, carries certain assumptions which are not limited only to this author or this specific methodology and, as discussed below, they limit the understanding of temporality in static image.

Rose (2012, p. 19) defines three sites from which static image methodologies are articulated: "the site of production, which is where an image is made; the site of the image itself, which is its visual content; and the site where the image encounters its spectators or users, which is the site of audience". Each of these three sites usually unfolds in three approaches that are hinged in different ways for each one. These are: 1) the technological approach (which emphasizes the apparatus characteristics from which the image was produced); 2) the compositional concern (whose focus is on strategies used for the arrangement of the elements that form the image); and 3) the social approach (which focuses is on the political, economic and corporate relationships involved).

Therefore, the site of production, for example, will emphasize characteristics of the device used for image production (camera, lens and technical expedients used) in its technological approach, as well as the compositional consequences that such technical expedients generated and the effects of these technologies in social terms.

In photography, one of the authors that stand out in this approach is Vilém Flusser, which states that photojournalism can be thought only in relation to the apparatus in which it appears. To 
him, "although the photograph today is still largely a leaflet form, and although it might thus be distributed in an archaic, hand-tohand manner, immense and complex apparatus for photographic distribution have come about", so that "the fact that the various complex apparatus divide photographs into various channels: the apparatus channels photographs" (FLUSSER, 2000, p. 25). The meaning effects (compositional field) and the social relations articulated by photographs, therefore, are subject to the technological field of their production and to their conditions of distribution and publication.

In terms of studies that emphasize the image itself, there are the semiotic approaches, in which the field of enunciation is highlighted. This is a field that seeks meaning effects and rhetorical constructions, either from the enunciations produced by each device, from the image's compositionality or from sensory experiences articulated in the image and interpreted from a culture and a discourse.

Among several authors in this field, we can cite as examples the approaches of Umberto Eco and Roland Barthes, widely used for the analysis of photojournalism. Barthes elects connotation as a privileged concept for understanding the movement of meanings that are articulated in representational codes. Regarding photograph, Barthes (1986) will describe a series of pictorial mechanisms of connotation. For him, it is not possible to say that a picture connotation form a kind of structure, but it gives photography other layers of meanings beyond referential elements of image. That allows that photographers hide the preparation that undergoes the scene captured. These connotations elements include, for example, truncation (mechanism in which the photographer approaches artificially figures that are originally separated from an operation of montage), the actor's pose and the objects in the scene (because both carry culturally marked meanings).

Eco (2007) states similar assumptions. For image analysis, he proposes its decomposition into five levels: the iconic level (denotation elements, which includes concrete image data and graphics elements of the reference object), the iconographic level (connotation plan, composed by the elements whose significations are given by conventional meanings arising from a cultural learning), the tropological level (traditional figures of speech applied to the visual representation), the topic level (argumentative sites and premises that are articulated in the image), and the enthymematic level (conclusions triggered by the arguments constructed in the previous levels). 
Finally, methods which emphasize the site of audience can also be divided analogously. These are studies that demarcate the notion that pictures meanings are constantly renegotiated by the audience. In this way, itineraries of an image reading are always unpredictable: each viewer will give a specific meaning to photography based on their own reading itineraries, personal experiences and cultural background. Cultural studies and image ethnography studies are particularly fruitful in this field, to propose different approaches in understanding the intersection between the world configured by the poetic production and the knowledge accumulated by the audience.

After that, the question that this article aims to discuss is: what is the place given to the narrative in each of these theoretical perspectives? Or, in more precise terms, how photojournalistic narrative can be thought in each one of them?

All those forms of analysis carry some common assumptions. Firstly, in all of them, the static image carries certain decipherable elements that must be made intelligible for analytical work - although the choice of these elements changes from one approach to another. That is to say that the image elements "mean" only if materialized in the image (in the enunciation itself), so that there is no "before" or "after" in the image that could form a narrative.

We can also say that, although these theoretical perspectives assume that image does not keep a mimetic relationship with reality, yet the primacy of meaning is given to the primacy of referent because only what is seen is worthy to be analyzed - even when that referent is taken as disfigured, tortured and refigured for the technological apparatus, for the dominant discourse, for the meaning production strategies or for the spectators' eyes.

And, precisely because of this, the temporality engendered in these theories can only be a static temporality, which expels the narrative of photojournalistic image by denying that it has duration. For the static image, would matter only the function of showing and describing, not of narrating. Photojournalism, therefore, could not tell a story, but only describe a set of things (even if it is a distorted description).

Based on Didi-Huberman (2013), it can be said that the problem of such methods is in the fact that all of them elect a privileged tripod of analysis categories: the visible, the legible and the invisible. The visible represents the pictorial elements that form the image, which can be discerned as signs. In contrast, the invisible 
occupies everything that is not put in that first domain. The legible engenders the translatability - the space in which the signs of visible are delivery to the interpretation of a reader, a discourse or a domain of knowledge.

"Posing one's gaze to an image, then, becomes a matter of knowing how to name everything that one sees - in fact, everything that one reads in the visible" (DIDI-HUBERMAN, 2005, p. 3). Posterity, deformation and elaboration do not enter in the analysis work.

Such approaches, to Didi-Huberman (2005, p. 122), "delivered up all images to the tyranny of the concept, of definition, and, ultimately, of the nameable and the legible". Paying attention to "graphic sign that abbreviates a signature", it "carries within it the power to name" (DIDI-HUBERMAN, 2005, p. 136). Doing so, these approaches try to control the contradictory aspects of the visible.

Moreover, for the author, such approaches have had the effect of killing the image itself. This is because killing the image means the wish "to extract from a subject that is always rent, contradictory, unconscious, in a sense 'stupid', the harmonious, intelligent, conscious, and immortal humanity of man". As opposed to this, it is necessary to insert in static image studies another kind of subject, which "thinks itself only as divided, rent, fated to die" (DIDIHUBERMAN, 2005, p. 219).

To bring back temporality (and thus narrative) to static images, such as photojournalism, it would be necessary to untie theory from the structures of the visible and the legible, exploited by all methodologies mentioned above, and think the image from the point of view of another record: the domain of the visual.

\section{NARRATIVE IN THE DOMAIN OF VISUAL: SYMPTOM AND TIME}

Didi-Huberman (2005) will oppose the paradigm of visible for the narratological analysis of static pictures with another model that selects the symptom as a key concept to the analysis. For him, in methodological terms, the use of semiotics and of the paradigm of visible for image analysis had the effect of engendering only three possible understanding categories for the image: the visible, the legible and the invisible. To this "incomplete semiology", he challenges an idea from which "the efficacy of these images is not due solely to the transmission of knowledge - visible, legible or invisible 
-, but that, on the contrary, their efficacy operates constantly". This would require a methodological look that embraces "something like a suspended attention", "a phenomenology of the gaze, perpetually subject to projection and transference (...) to displace its paths and make them signify elsewhere, otherwise". This elsewhere is the place of the symptom, the place that, beyond semiotic categories, could introduce the visual and the figurability.

That is how his argument is structured: if the image undoubtedly is formed by culturing loans, it also consists of "interruptions effected in the discursive order" and therefore "of transposed legibilities, but also of a work of opening - and thus of breaking and entering, of symptom formation - effected in the order of the legible, and beyond it" (DIDI-HUBERMAN, 2005, p. 20). This interruption in the legible discourse is the site of the symptom.

Let us define the terms. The symptom for psychoanalysis is a "sovereign accident": in precise terms, a symptom "is, for example, the moment, the unpredictable and immediate passage of a body into the aberrant, critical state of hysterical convulsions, of extravagance in every movement and posture: gestures have suddenly lost their 'representativity', their code” (DIDI-HUBERMAN, 2005, p. 260).

For image analysis, interests "the disfigured, deformed, and above all meaningless character that such bodily accidents present to the eye" (DIDI-HUBERMAN, 2005, p. 332). This is an approach that does not seek in the image those elements that corroborate with the formation of meanings, but rather, that seeks the contradictory points that resignify, refigure (or even contradict) the imagistic data.

There is in the concept of symptom a semiotic specificity that is very useful for the study of static images. This is because:

\footnotetext{
The symptom is a critical event, a singularity, an intrusion, but it is at the same time the implementation of a signifying structure, of a system that the event is charged with making surge forth, but partially, contradictorily, in such fashion that the meaning is expressed only as an enigma or as the 'appearance 'of something', not as a stable set of meanings. That is why the symptom is characterized simultaneously by its visual intensity, its value as radiance, and by what Freud calls here its suitability to 'conceal' the 'unconscious fantasy that is at work' (DIDIHUBERMAN, 2005, p. 261).
}

Of this stretch, it appears that the symptom is itself an event or a happening (and not exactly a photography fragment). And, in addition, symptom refuses totalizing interpretative syntheses, insofar as its main characteristic is precisely to make that conflicting 
meanings may be related. Freud "focused on the symptom as on something that breaks up all discursive unity, as on what intrudes upon and smashes the order of the Idea, opens systems and imposes something unthinkable" (DIDI-HUBERMAN, 2005, p. 169). Symptom symbolizes and represents from the deformation, so that the same element can represent one thing and its opposite at the same time.

What does it means to see symptom on photography? The symptom's content in photography is that one given by the individual who provides meaning to the significant, filling the semantic emptiness in representation, even when he is not aware of it. This is not about, however, a subject that fills the meanings emptiness from his cultural backgrounds or his identity formation (aspects that, in different ways, are included in other analytical models), but a subject who sees himself in the image and, doing so, constructs a "before" and an "after" for photography.

Such "before" and "after", however, do not belong to the domain of visible or legible, but to the domain of symptom, in a way that the story told can be any story - even a story that is openly contrary to the significant elements that are seen in the visible field.

There is here, therefore, an analysis model that is essentially different from the previous one. The approach which emphasizes the visible "cuts the image short so as to give it meaning, and polarized it over the unity of a synthesis; it saw in the symbol a kind of intelligible unity or schema between the general rule and the singular event". But Didi-Huberman's proposal (2005, p. 231) "does not deny the symbol, it simply specifies that the symptom delivers its symbolicity 'in the sand of the flesh'. This clearly changes everything about the way we think about the symbol itself". Thus, if the symbol was earlier thought "in terms of its meaning, which is to say its signified content", with the symptom, in contrast, the thought is directed to a work whose meaning "we are constrained to take into account, at last resort, in the crude and material terms of the signifier, which has multiple effects: the 'ascending ramification' of associative meanings" and also "the juxtaposition of equivocal knots and the conjugation of symbolic treasure with markers of not-meaning" (DIDI-HUBERMAN, 2005, p. 178).

It is about the recognition that static images never mean unequivocally. As Didi-Huberman (2005, p. 262) states, if “it's being understood that every pictorial figure presupposes 'figuration', just as every poetic statement presupposes enunciation", "it turns out that the relation between the figure and its own "figuration" is never simple: 
this relation, this work, is but a skein of paradoxes", so that "the image effectively knows how to represent both the thing and its contrary".

The narrative engendered by photography from the perspective of the symptom is not the narrative of the decipherable symbol; it is the narrative of someone who does not see the picture, but sees himself in it. It is in this domain of symptom that it can be articulated the visual (as opposed to the visible).

The visual, in this sense, is a surface of expectations that "takes us out of the visible and 'natural' spectacle; it takes us out of history and makes us wait for an extreme modality of the gaze, a dreamed modality, never completely there, something like an 'end of the gaze"' (DIDI-HUBERMAN, 2005, p. 25), because has a fantasmatic nature. This is an area where the code gives way to associations.

It is in this space that figurability is produced:

\begin{abstract}
figurability stands opposed to what we habitually understand by "figurative representation," just as the visual moment, which it makes happen, stands opposed to, or rather is an obstacle to, an incision in, a symptom of, the "normal" regime of the visual world, a regime wherein we think we know what we are seeing, which is to say wherein we know how to name every appearance that it pleases the eye to capture (DIDIHUBERMAN, 2005, p. 28).
\end{abstract}

In other words, "to experience a constitutive and central rift: there where self-evidence, breaking apart, empties and goes dark" (DIDI-HUBERMAN, 2005, p. 7).

Figurability, therefore, does not bend to iconographic meanings: on the contrary, it modifies figures, it disfigures the visible, and it makes the image "speak" what we want to hear from it. More than that, figurability dramatizes the visible: by opening representation, it does not exclude similarity, but "make resemblance work as a drama - and not as the simple successful effect of a mimetic technique" (DIDI-HUBERMAN, 2005, p. 211).

The study of symptom and figurability on photojournalistic image implies the adoption of a specific conceptualization of temporality - concept that will structure narrative and build the place where the story can be thought and developed. Such repositioning in the understanding of static images that these two concepts engender makes it necessary "to return to an inflection of the word that speaks neither of imagery, nor of reproduction, nor of iconography, nor even of 'figurative' appearance". It would be "to return to a questioning 
of the image that does not yet presuppose the 'figured figure' - by which I mean the figure fixed as representational object - but only the figuring figure, namely the process, the path, the question in action" (DIDI-HUBERMAN, 2005, p. 141).

This is a temporality in which the process (as opposed to the finished figuration) is in the foreground. Time opens itself to the image once, in the symptom, meaning is never linear, but it is built from a constant return to the sphere of the past and to the sphere of desire.

\begin{abstract}
Little by little, then, our sense of the image's temporality changes: its character of obscured immediacy passes into the background, so to speak, and a sequence, a narrative sequence, appears before our very eyes to offer itself for reading, as if the figures seen in a flash as motionless were henceforth endowed with a kind of kinetics or temporal unfolding. No longer the permanence of crystal but the chronology of a story (DIDIHUBERMAN, 2005, p. 13).
\end{abstract}

Looking into pictures in this theoretical light denotes a displacement in a particular notion of temporality linked to the analysis that focuses on the visible. Didi-Huberman (2005, p. 178) states that "the model of temporality presupposed by the iconological operation developed as a deduction, we perceive that it always requires a direction, in other words a temporal progress". The temporal constraint of the symptom is quite other. "There is nothing in it that disappears to make way for something else that will follow it or mark it with the triumph of a progress. There is only the troubled play of advance and regression all at once; there is only mute permanence and unexpected accident at the same time". In a more radical way,

In fact, over-determination opens the time of the symptom. It gives access to the present only through the element of a conflict or equivocation, which themselves reference other conflicts and other equivocations, past yet persistent, mnemic elements that come to distort the present of the subject by giving form to its symptom (DIDI-HUBERMAN, 2005, p. 178).

Temporality, seen from the perspective of the symptom, makes that time and duration are reduced to a realm of memory: "the visual event of the painting happens only starting from this rend that, before us, separates what is represented as remembered from everything that presents itself as forgotten" (DIDI-HUBERMAN 2005, p. 157). As any realm of memory, a picture read from the visual domain "is a distorting mirror, twisting its own themes in ways that 
define its significance" (NORA, 1996, p. 15). These realms of memory are always objects en abime, "which is to say, objects containing representations of themselves (hence implying an infinite regress)" (NORA, 1996, p. 16) and cannot be reduced to signs: "unlike historical objects", realms of memory "have no referents in reality; or, rather, they are their own referents".

Once explained that the temporality in photojournalism can be thought as the coadunation between the past of the manifested symptom (the image looking back at us) that refigure the present and the visible itself, engendering the space of visual from contradictory meanings, how can narrative be thought?

\section{FINAL REMARKS: PHOTOJOURNALISTIC NARRATIVE BETWEEN VISIBLE AND VISUAL}

Once exposed the terms, we can say that photojournalism's temporality (and therefore its narrative articulation, its composition of intrigue) is in the intersection of visual and visible, from where it will take its comprehensibility.

The reading of photographs is thus a floating reading, in which significants fit in different meanings (often contradictory with each other and not related to photographer's intention). Photojournalistic narrative, in this sense, says something about who looks and not about what is looked or about who photographed it.

As narrative weaves a fabric with temporality, photography, from the perspective of symptom, takes narrative as a ripped representation: "to think the fabric (the fabric of representation) with its rend, to think the function (the symbolic function) with its interruption or its constitutional dysfunction" (DIDI-HUBERMAN, 2005 , p. 144). With the linear temporality of iconographic elements (or, in other words, the visible) it is summed the deviant temporality of memory and desire: "so we understand that the incapacity or rend functions in dreams as the very motor of something that will be between a desire and a constraint - the constraining desire to figure. To figure despite everything, thus to force, thus to rend" (DIDIHUBERMAN, 2005, p. 153). In this interstitial, there is no sense in separating what is from the order of the visible and what is from the subjects' projection - both of them are related when journalistic photography tells a story in a game that belong to the field of desire. 
And this is precisely the argument put forward by DidiHuberman in his works on interpretation of art history: symptom appears when the subject feels subjected by the image and, therefore, feels under image's gaze. The static image, therefore, when looked, look us back and tell us something very particular. Thereby, it opens another temporality, ripping the enunciation elements in the figures. And that is what, for him, "we are before the image as before the unintelligible exuberance of a visual event" (DIDI-HUBERMAN, 2005, p. 228).

In the coadunation between the visual and the visible lies a "before" and an "after" for photojournalistic image, so that we can say that it tells a story. This story, however, does not say much about the event that motivated the photography, although its evidentiary marks are still in the visible spectrum, but tell us something about whom the story challenges as its interlocutor in the domain of visual.

Reconcile the visible and the visual means to articulate the viewpoint of structure (understood as the legibility in the visible domain) with the viewpoint of event (or the symptom). "With the visible, we are of course in the realm of what manifests itself. The visual, by contrast, would designate that irregular net of event-symptoms that reaches the visible as so many gleams or radiances". It is about "a work, a memory in process that has nowhere been fully described, attested, or set down in an archive, because its signifying 'material' is first of all the image" (DIDI-HUBERMAN, 2005 , p. 31). It is in the intersection of the visual and the visible that we find the temporality and the narrative articulation of the static images. More than that, we can say that the narrative temporality in photojournalism is in "the anadyomene movement of the visual in the visible and of presence in representation" (DIDI-HUBERMAN, 2005, p. 212).

For photojournalism, such acceptation has important consequences that dislocate a number of its traditional narrative assumptions. Photojournalistic storytelling has never been thought as a narrative that would mirror the external events, although this was always object of its desire. W. Eugene Smith, one of photojournalism's fathers, had written that "those who believe that photographic reportage is selective and objective, but cannot interpret the photographed subject matter, show a complete lack of understanding of the problems and the proper workings of this profession". This is because "the journalistic photographer can have no other than a personal approach; and it is impossible for him to be completely objective" (SMITH, 1948, p. 4). 
From the perspective of symptom, it is not a machine, a photojournalist, a cultural affiliation or a complex representational structure that can never be objective (or, in more precise terms, it is not just that): it is a kind of look that is markedly symptomatic and, therefore, capable of engendering any storytelling, any narrative, supported by the wandering temporality of subjects' symptoms.

"Here we come face-to-face with the symptom as with a kind of constraint to unreason, where facts can no longer be distinguished from fictions, where facts are essentially fictive and fictions efficacious" (DIDI-HUBERMAN, 2005, p. 159). The photojournalist in this respect "is, in every sense of the word, only the fictor, which is to say the modeler, the artisan, the author, the inventor of whatever past he offers us" (DIDI-HUBERMAN, 2005, p. 2 ) and generates the space in which we enter, with our own ghosts, in its imbrications of meaning.

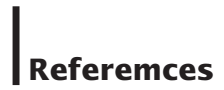

BARTHES, Roland. Lo obvio y lo obtuso. Buenos Aires: Paidós, 1986.

CARTIER-BRESSON, Henri. The decisive moment. New York: Simon and Schuster, 1952.

DIDI-HUBERMAN, Georges. Confronting Images. Pennsylvania: The Pennsylvania State University Press, 2005.

DUBOIS, Philippe. O ato fotográfico e outros ensaios. Campinas: Papirus, 1993.

ECO, Umberto. A estrutura ausente. São Paulo: Perspectiva, 2007.

FLUSSER, Vilém. Towards A Philosophy of Photography. New York: Reaktion Books, 2000.

GENETTE, Gérard. Narrative Discourse. New York: Cornell University Press, 1980.

METZ, Christian. Film Language: a semiotics of the cinema. Chicago: The University of Chicago Press, 1991.

NORA, Pierre. Realms of memory: the construction of the French Past (volume I: Conflicts and Divisions). Nova lorque: Columbia University Press, 1996. 
RICOEUR, Paul. Time and Narrative - volume 1. Chicago: Chicago University Press, 1990.

RICOEUR, Paul. “Arquitectura y narratividad”. Arquitectonics. Barcelona: Ediciones UPC, 2002.

RICOUER, Paul. "Entre tempo e narrativa: concordância / discordância". Kriterion, v. 53, n. 125, Belo Horizonte, Junho de 2012.

ROSE, Gillian. Visual methodologies. Califórnia: SAGE, 2012.

SMITH, W. Eugene. "Photographic Journalism". In Eugene Smith, Photo Notes. Connecticut: Jerome Nevins, 1948.

Eliza Bachega Casadei holds $\mathrm{PhD}$ in Communication Sciences from Escola de Comunicações e Artes da Universidade de São Paulo (ECA-USP) and photojournalism professor at Faculdade de Arquitetura, Artes e Comunicação da Universidade Estadual Paulista Júlio de Mesquita Filho (FAAC-UNESP). E-mail: elizacasadei@yahoo. com.br. 